Ines Voršič

University of Maribor**

\title{
WORD-FORMATIONAL PRODUCTIVITY OF THE SLOVENE LANGUAGE IN THE CASE OF SPORTS NEOLOGISMS
}

\section{INTRODUCTION}

1.0 At the turn of the $21^{\text {st }}$ century, the world has been undergoing enormous changes reflecting the current global trends towards an amalgamation of local economic, cultural and social structures into broader multinational conglomerates. The main goal of these conglomerates is to enable the flow of capital, ideas and products finding their way into our everyday life (Vuković 2011: 19). Heavily promoted by advertising, these new products produce new lifestyle trends, such as having a successful career, practicing functional use of modern technology and using safe and ecological means of transportation, but above all, modern society values an attractive physical appearance based on the achievement of good physical form.

1.1 These lifestyle trends reflect those areas which have been developing very rapidly, also linguistically, because they have some kind of impact on the general population. These areas include advertising, mobile phone communication, electronic communication, fashion, cosmetics, the car industry, cuisine and sport. In the case of the Slovene language, studies have already been conducted on the use of complex words in the car industry (Bokal 1998), mobile phone communication (Stramljič Breznik 2010) and advertising (Stramljič Breznik, Voršič 2009), so the present study focuses on the field of sports.

\section{METHODOLOGY}

2.0 The article deals with the word-formational characteristics of lexical items that belong to the most general semantic field of sports, further specified by the hypernym the type of sport (based on the number of participants). This yields a sample of controllable size containing lexemes with comparable semes which already belong to the general body of Slovene lexis (e.g. according to the Slovar slovenskega knjižnega jezika/Dictionary of the Slovene standard language (hereafter - SSKJ): football is 'a sports game in which players try to kick a ball into a goal') as well as the terminolog-

\footnotetext{
* Author's address: Filozofska fakulteta v Mariboru, Oddelek za slovanske jezike in književnosti, Koroška cesta 140, 2000 Maribor, Slovenia. Email: irena.stramljic@uni-mb.si

** Author's address: Filozofska fakulteta v Mariboru, Oddelek za slovanske jezike in književnosti, Koroška cesta 140, 2000 Maribor, Slovenia. Email: ines.vorsic@uni-mb.si
} 
ical part of Slovene lexis (futsal 'a variant of football played by only seven players on a relatively smaller pitch'). The selected lexical items are then analyzed from the perspective of word-formation. Special attention is given to those complex words from the selected word families that represent more recent and word-formationally less established lexis, i.e. words with the status of neologisms and potential complex words as well as nonce words.

2.1. The data on the selected lexis was collected from the Slovene reference corpus of texts FidaPLUS with the help of the multifunctional tool Sketch Engine (abbr. SkE). This tool enables classic functions for concordances (search for lemmas, word forms, phrases, search with the CQL language) and standard forms of presenting, classifying, filtering and saving concordances. Additionally, it enables other types of analysis, such as the creation of the Word List, the use of Thesaurus and Word Sketch, as well as Sketch-Diff. In view of these possibilities, the corpus approach is suitable for the analysis of established as well as less established or not yet established lexical characteristics of language, which in our particular case refers to the field of sports. Our research relies heavily on the corpus function of the world list, which enables the extraction of all the word forms or lemmas in the corpus and ranks them by frequency, while also enabling the extraction of groups of words which stem from the same root. Our study is based on the words which were extracted by searching for the root of the word (e.g. *ples. *), yielding the word family of the lexeme ples. The analysis only included those words that occurred in ten tokens at the most (which was only the case in two examples, the majority had a much lower count), because our focus was directed at the analysis of recent lexis with low token counts. In lexicography, what counts as relevant data is the occurrence of a lexeme in three different independent sources (Stramljič Breznik 2004). In the study presented here we were interested in words which have not yet established themselves and which are still making their way into the lexical inventory of the Slovene language. For this reason we followed the criterion according to which the token does not appear in more than in three different sources. Lexical units that were the result of typing mistakes were also excluded.

\section{DEFINITION OF BASIC LEXICOLOGICAL CONCEPTS}

3.0 Methodological framework contains several lexicological concepts, such as the semantic field, word family, complex word, neologism, potential complex word and nonce word. For the purpose of clarity these concepts have to be given a general definition and illustrated with concrete examples.

3.1. In order to achieve an objective selection of lexemes from the field of sports, we have to keep in mind that the lexical structure of language is systemic. According to Jost Trier (1931), who is considered the founder of the theory of systemic lexical structure, the whole lexicon of a language works as a structure of interconnected fields which are organized in a hierarchical and paradigmatic way, and these fields themselves have a structure consisting of conceptually related words. 
In Slovene linguistics, the overview of the concepts and terminology used for naming semantically organized groups of words by Stramljič Breznik (2007: 97 - 109) has attracted a high level of interest from numerous authors, inciting a discussion involving different positions. In Slovene linguistics, just as in other countries (Nikolić-Hoyt 2004: 109), the concept of the lexical organization of language originated primarily from practical considerations of lexicography and not from theoretical considerations of semantics. In the year 2000 a number of conceptualizations of possible terminological groups emerged, which resulted in several versions of the terminology. In Slovenska slovnica/Slovene Grammar (Toporišič 2000: 118, 1996: 89) the term word field (besedno polje) is used, defined as a group of closely connected words that name extra-linguistic reality by sharing the same spatial, temporal or causal frameworks. In their textbook, Križaj Ortar, Bešter Turk et al. (2000: 13 -18) use the term thematic field, defining it as a group of words whose use in a text can be predicted solely on the basis of the topic or the title of the text. The third term, which was introduced by Vidovič Muha (2000: 59), is semantic field, defined as a conceptual field structured by semantic constituents, i.e. cognitive reality formed by the classifying semantic constituent.

In order to find an appropriate selection of lexemes for the purposes of this research we had to take into account the concept of semantic field, which was at first specified as the most general semantic field of sports. Within the general field, three semantically more specific semantic fields were determined: first, team sports with a selection of basic lexemes: football/footy ; handball, volleyball, basketball, ice hockey, baseball, rugby, etc; second, individual sports: athletics, gymnastics, cycling, motor sports, tennis, wrestling, boxing, karate, fencing, swimming, sailing, skiing, sledding, ice skating, surfing, golf, rollerblading, body building, etc. Potentially, there is a third semantic field, which can be defined by the hypernym pair sports, such as dancing, rowing (e.g. coxless pair). Here it has to be noted that the structuring of the semantic fields solely on the basis of the number of participants, while appropriate for the purpose of this research, does not exclude other various possible classifications of varieties of sports on the basis of other criteria, such as the space in which it is carried out (e.g. indoor v. outdoor sports), the object used in the sport (ball, puck, target, bicycle, etc.), skills involved (fighting v. non-fighting sports), the way it unfolds (water sports, air sports), the season in which it is carried out (winter v. summer sports), etc.

The selection of lexemes from individual semantic fields was implemented on the basis of two criteria. The first criterion was the visibility and popularity of the sport in Slovenia, e.g. semantic fields such as those of baseball and rugby were excluded. The second criterion included the number of motivated words. In others words, the selection included those lexemes from which a greater number of complex words were formed, and which thus presented the basis of a larger word family.

3. 2. A complex word is a motivated word which is semantically and formally related to its motivating word at the synchronic level. It is a bipartite word, consisting of a base and an affix or affixes. A group of complex words sharing the same root is 
called a word family (Toporišič 1992: 7; 1996: 89; 2000: 108, 116); Vidovič Muha 2000: 107 - 108); Stramljič Breznik 2004).

In our particular case, the inclusion of all the members of the word family of a selected lexeme from a particular semantic field would miss the purpose of the study, because our interest was in more recent, not yet established expressions, which are characterized by a low count. The complex words selected thus had the status of neologisms, more specifically the status of a potential word or a nonce word. 3.3. Neologism is a term which is mostly used to refer to new words. Such use of the term, however, is only valid in the case of new expressions created for a new concept. For this reason, the most appropriate definition of neologisms is the one which is based on the place of new lexemes in the existing lexical structure. Neologisms can thus be defined as those words which have the potential to become a unit of langue, i.e. a potential to enter the lexical system of the language (Martincová 1972). On the basis of necessity, neologisms are divided into necessary and stylistic neologisms. The former are new expressions created for naming new objects or phenomena, i.e. filling a lexical gap, while the latter are ad-hoc words created for a specific occasion (MuhvićDimanovski 2005: 6 - 7). Stylistic neologisms are formed in parallel to already existing expressions and are mostly context-dependent and therefore expressive.

In Slovene linguistic literature, a neologism is defined as a new word (Slovenski pravopis/Slovene Ortography), and as a not yet generally established word or phrase (SSKJ, 1998). Toporišič (1992: 2001) defines a neologism as a newly formed word or phrase or an old word or phrase used in a new way, explaining it as a recent formation, a temporally marked word which can become a part of neutral vocabulary through frequent use, otherwise remaining an ad hoc formation (Toporišič 2000: 130). These definitions imply a distinction between a new word (a neologism) and an ad hoc word (a nonce word). Nonce words can be defined as words created for a particular occasion, as words which "the speaker forms according to regular word-formational patterns and are understood by the hearer or reader. But they do not become part of general usage" (Toporišič 2000: 130 - 131), and are not institutionalized because they are limited to particular speech or textual situation (Toporišič 1992: 222).

By taking into account the corpus data about the occurrence and the systematic nature of their formation, the study included those neologisms that fall into the following three categories. The first category comprises complex words which are formed according to the existing word-formational patterns and have the potential to enter the lexical system, while the second category comprises complex words which are formed according to the regular word-formational patterns, but have a marked combination of bases and/or affixes. The third category consists of those complex words which are very individual and are not created according to regular patterns or do not have a predictable morphemic combination. According to this classification, only the complex words from the first category have the status of neologisms as potential lexical units, while the second and the third categories deviate from that by entering the sphere of individual and ad-hoc usage, showing creativity in language use and intentional expressiveness. 


\section{SELECTION OF MATERIAL}

4.0 On the basis of the above-mentioned methodological framework and according to the theoretical definition of the key terms specified for the purpose of this research, a selection of the following base words (i.e. motivating words) yielding low frequency complex words which have not yet established themselves as part of vocabulary have been selected.

\subsection{Sports}

The word family with the base word šport (sport) includes the following lexemes:

aerošport (1), antišportnica (1), antišportnik (1), bikešport (2), kvazišportnica (1), kvazišportnik (1), nešport (1), neošportnik (1), športoid (1), športoljubec (1), športolog (4), športoslovec (3), športologija (5), športokracija (2), športovščina (7), športmen (1), športnež (3), športščina (3), ultrašport (2), ultrašportnik (1), vsešportnik (1), žogošport (2); antišporten (1), jugošporten (2), kvazišporten (1), meďsporten (1), multišporten (1), parašporten (1), pošporten (1), polšporten (1), športnoaktiven (3), športnojahalen (1), športnokomentatorski (1), športoholičen (1), športološki (1), športosloven (3), ultrašporten (1), velešporten (1), vsešporten (1), zabavnošporten (1), zašportan (1), žogošporten (2); športajoč (1).

From the semantic field team sports the following lexemes yielding members of word families have been selected:

"Nogomet"/"fuzbal"/"nogobrc" (standard and substandard terms for football): antinogomet (3), antinogometaš (1), evronogomet (1), jugonogometaš (1), nadnogometaš (1), najnogometaš (2), nogomanija (1), nogometafizika (2),nogometarjenje (1), nogometaška (1), nogometnik (1), nogometoljubec (1), nogometolog (1), nogometomanija (1), nogometoslovec (1), nogometšcina (6), pranogomet (1), slačinogometaš (1), supernogometaš (1), velenogometaš (1), velikonogometaš (3); antinogometen (1), jugonogometen (4), mednogometen (1), nadnogometen (1), nogometalen (1), obnogometen (7), protinogometen (3), sociološko-nogometološki (1), velenogometen (2), velikonogometen (7); ponogometiti (1); fuzbalček (1), fuzbalerščina (1), fuzbalfen (2), fuzbalogija (1), fuzbalolog (1), fuzbalomanija (5), fuzbalšcina (9), jugofuzbal (1); antifuzbalski (1); nogobrc (3), nogobrcar (1), nogogazem (1), nogohitrec (2), nogoljublje (1), nogovanje (1).

"Košarka"/"basket" (standard and substandard term for basketball): evrobasket (2), košarkašenje (3), košarkiranje (2), jugokošarkar (3), minikošarka (3), najkošarkar (2), nekošarkar (1), nekošarkaš (1); jugokošarkarski (81), nadkošarkarski (1), obkošarkarski (1), vodnokošarkarski (2); basketaš (3), basketiranje (2), minibasket (4); basketaški (1).

"Rokomet" (handball):

minirokomet (2), rokometec (2); minirokometen (1), obrokometen (2), predrokometen (1), rokometnonogometnekošarkarskokolesarski (1). 


\section{"Hokej" (hockey):}

hokejka (3), hokejščina (4), nehokejist (1), prahokej (1), rolerhokej (1); hokejaški (6), nehokejski (4), obhokejski (1).

"Odbojka" (volleyball): miniodbojka (3), nogoodbojka (1); kvaziodbojkarski (1); priodbojkirati (1).

4.3 From the semantic field of individual sports the following lexemes yielding suitable family members have been selected:

\section{"Smučanje/skijanje" (skiing):}

e-smučař̌čina (3), parasmučar (1), prasmučar (2), smučanorija (2), smučarajanje (1), smučarščina (2), smučerator (1), smučkice (1), supersmučar (2), supersmučarka (2); alpinističnosmučarski (2), predsmučarski (2), smučarskorekreacijski (1), smučarskotekaški (10), smučiščarski (2), smučljiv (6), velesmučarski (1); posmučati (1); skijanje (2), ${ }^{1}$ skijač (1), skijaš (1); skijaški (2).

\section{"Atletika" (athletics):}

atleticizem (1), atletičnost (1), atletizacija (1), atletizem (5), atletskost (1), atletstvo (1), nadatlet (1), najatletinja (1), psevdoatletika (2), superatletinja (1), turboatlet (1); atletičen (2), superatletski (1); atletizirati se (1).

"Golf" (golf):

golfac (6), golfhec (1), golfiat (1), golfija (2), golfin (1), golfivec (1), golfizem (1), golfliga (2), golfman (1), golfmanija (1), golfsafari (3), golfščina (1); antigolfovski (1), obgolfski (2), pogolfski (1), velegolfski (1); golfissimo (1).

"Kolesarstvo" (cycling):

kolesarijada (3), kolesarnina (1), nekolesar (1), prekolesarjenje (1), sokolesar (2), ultrakolesar (5); postkolesarski (1), protikolesarski (1), razkolesarjen (1), ultrakolesarski (1), velekolesarski (2); pokolesariti (5), obkolesariti (8).

"Fitnes" (fitness):

akvafitnes (2), fitnesar (2), fitneser (6), fitneserka (1), fitnesindustrija (1), fitnesiranje (2), fitnesjoga (1), fitnesmojster (1), fitnesmuzika (1), fitnesrevolucija (1), fitnesrutina (1); fitneserski (1), sfitnesiran (2); fitnesirati (1).

"Tenis" (tennis):

minitenis (7), tenisačenje (1), tenisačina (2), tenisarka (10), tenisiranje (2), tenisišče (1), teniščina (3); tenisaški (3), tenisšpilen (1); tenisirati (4).

\footnotetext{
${ }^{1}$ In the corpus this word has 7 occurences, but in five of these cases it has been used in a
} text in Croatian. 
"Sankanje" (sledding):

sankalec (2), sankarija (6), sankarijada (1), sankaštvo (1), sankijada (1); sankarski (1); presankati (1), zasankati se (1).

"Kegljanje"/"bovling"/"bowling" (bowling):

keglijada (1), nekegljač (1); bovlišče (4); bovlinški (1); bowlingaš (1); bowlati (1), pribowlati (1).

"Boks" (boxing):

boksaerobika (1), boksališče (1), boksarščina (2), brcoboks (9), brcoboksar (1); boksarskonazorski (1).

"Karate" (karate):

karatejec (2), karatejka (1), karateseks (1), kvazikarate (2).

4.4 From the semantic field of pair sports only one lexeme with the related word family members has been selected:

"Ples" (dancing):

antiples (2), neples (2), plesač (8), plesarija (2), plesoholičarka (1), plesoljubec (2), plesovodja (3), postples (2), soloplesalec (1); ognjenoplesen (1), plesajoč (1), plesaželjen (1), plesnobaleten (1), plesnodramaturški (1), plesnoizrazen (1), plesnokoreografski (1), plesnomoden (1), plesnoritmičen (2), plesolomen (1), psevdoplesen (1).

\section{WORD-FORMATIONAL ANALYSIS}

5.0 The word-formational analysis is based on the structural-semantic principle. This means that complex words have been analyzed in terms of their structure - in terms of their formation, word category and affixes. The semantic analysis has focused on their word-formational and lexical meaning. On the basis of predictable or unpredictable patterns and morphemic combinations used in their formation, the studied complex words have been classified into the following three categories.

\subsection{Potential complex words}

5.1.0 These include complex words formed according to predictable word-formational patterns, which means that they are less creative.

\subsubsection{Derivatives with suffixation}

5.1.1.1 Derivatives with suffixation include a considerable number of nominal complex words of feminine gender. These make use of the established inventory of Slovene suffixes. Semantically, they form a large group of feminine versions of masculine forms with the following suffixes: -ica (antišportnica, kvazišportnica), -ka (nogomataška, supersmučarka, fitneserka, tenisarka, - inja (najatletinja, superatletin$j a$ ). There is also an interesting use of the generalized suffix -ščina, formed on the 
analogy with the regular formation using the suffix -ina (slovenščina $<$ slovenski jezik), preserving the palatalized and assimilated part of the base which occurs in such cases. Complex words formed with -ščina have a different lexical meaning from those with -ina, Whereas words with -ina have the meaning of 'language or payment' (e.g. kolesarnina/cycling fee), those with -ščina form a group of new words used in computer games simulating a variety of sport (športovščina, nogometščina, hokejščina, šmučarščina, golfščina, boksarščina, teniščina; npr. Za začetek je premikanje igralcev $v$ tej teniščini tako počasno, nadzor pa tako nenatančen, da pri igranju bodisi zehaš, bodisi mečeš n-gage ob tla). In this semantic group there is one word which differs from the above words in terms of its base, namely tenisaščina, which is derived from tenisač (compare teniščina < tenis), and one which is different in terms of its suffix, namely karatejka.

A considerable group is comprised of derivatives with the suffix -ijada (kolesarijada, sankijada, keglijada), which remain within a productive and semantically predictable group with the meaning of 'sports event'. The only exception is sankarija$d a$, which denotes an activity and is used as a synonym for the dictionary word sankanje. Similarly there are derivatives with -izem, which retain the meaning of property or state (atleticizem 'athletic appearance'), but interestingly also as acts (atletizem 'athletic training'). The derivative with -arija can express a certain degree of positive connotation (sankarija), but at the same time this suffix can also have a negative connotation (plesarija). New complex words with the suffix -izacija also follow a predictable transformational pattern (atletizacija < atletizirati), using systemic deverbal derivation as in the example slovenizirati > slovenizacija. Complex words of neuter gender in this category mainly belong to the semantic group denoting the venue of the sports event and are formed with the predictable suffix -(l)išče (tenisišče, bovlišče, boksališče).

5.1.1.2 Adjectival derivatives with suffixation also make use of predictable suffixes, e.g. $-s k i$, which is added to nominal bases, but in this case the bases are stylistically marked (smučiščarski < smučiščar, fitneserski < fitneser, sankarski < sankar), -ki ( športološki < športolog, hokejaški < *hokejač). The same goes for deverbal derivatives in $-n$ (zašportan < zašportati se, sfitnesiran < *sfitnesirati se), -oč ( ̌́portajoč < športati, plesajoč instead of plešoč). Good use is also made of -ljiv with the meaning of inclination to act in the new word smučljiv. There is a considerable group of adjectival derivatives which are formed from a prepositional nominal phrase according to the predictable systematic pattern ta/tak, ki je Predl + Sam (he/she who is Prep + N): tak, ki je ob nogometu > obnogometen. Four prepositions are used in such cases: ob- (obgolfkski, obhokejski, obkošarkarski, obnogometen, obrokometen), po- (pogolfski, pošporten), med- (mednogometen, medšporten), and pred- (predrokometen, predsmučarski). The last three of the above-mentioned prepositions can also be interpreted as prefixes transformed from temporal adverbs potem $/ \mathrm{kas}^{-}$ neje, vmes and poprej, in which case they could also be classified as adjectival derivatives with prefixation. 
5.1.1.3 Verbal derivatives also follow the predictable denominal pattern with the suffix -irati (fitnesirati, tenisirati). The verbal derivation bowlati is particularly interesting as it consists of a foreign base and the native verbal morpheme-ati, which makes it a hybrid derivative.

\subsubsection{Compounds}

5.1.2.0 The corpus data confirms the well-known observation that nominal and adjectival compounds are predominant in the Slovene language, whereas verbal compounds are less frequent. According to the typology of lexemes in this category, the group of neo-classical compounds with combining forms (the so-called prefixoid and suffixoid formations) has to be mentioned first. The morphemic structure of these compounds includes truncated forms of generally used international root morphemes. The following examples from the corpus are typical nominal and adjectival prefixoid formations, with nominal and adjectival examples separated by a semi-colon:

akva- (akvafitnes), evro- (evrobasket, evronogomet), fitnes- (fitnesidustrija, fitnesjoga, fitnesmojster, fitnesmuzika, fintesrevolucija, fitnesrutina), jugo- (jugokošarkar, jugonogometaš; jugonogometen, jugošporten), kvazi- (kvazikarate, kvazišportnik; kvaziodbojkarski, kvazišporten), mini- (minikošarka, miniodbojka, minirokomet, minitenis), multi- (multišporten), neo(neošportnik), para-(parašporten), psevdo- (psevdoatletika; psevdoplesen), turbo- (turboatlet), vele- (velenogometaš; velegolfski, velekolesarski, velenogometen, velesmučarski, velešporten).

The following compounds belong to the category of the so-called suffixoid formations which have recognizable morphemes in the second part of the word:

-kracija (̌́portokracija), -log (nogometolog, športolog), -logija (športologija), -man/-men (golfman, športmen), -manija (golfmanija, nogomanija, nogometomanija,), -oid (športoid), -slovec (nogometoslovec, športoslovec).

Compounds in the category of compounds with combined interfixation and suffixation, which are mostly adjectival subordinate compounds, have a syntactic base which regularly contains a nominal phrase with a premodifying adjective ( $t a$, ki je povezan s smučarsko rekreacijo (he or she who is connected with ski recreation) > smučarsk-o-rekreacij-ski, alpinističnosmučarski, plesnobaleten, plesnodramaturški, smučarskotekaški, športnoaktiven, športnojahalen, športnokomentatorski, velikonogometen, vodnokošarkarski, zabavnošporten).

The group of compounds with interfixation contains both coordinate (sociološko-nogometološki), and even more frequently, subordinate adjectival and nominal compounds (boksaerobika, golfliga, vsešportnik; vsešporten, vsešportnik). The last example mentioned (vsešportnik) could also be classified as a nominal derivation from an adjectival base. 


\subsubsection{Derivatives with prefixation}

Due to globalization trends, there has been an increase in the number of hybrid derivatives with suffixation, i.e. derivatives which combine an international prefix with the native base, such as the following examples: anti- (antinogomet, antinogometaš, antiples, antišportnik; antigolfovski, antinogometen, antišporten), post-(postples; postkolesarski), super(supernogometaš, supersmučar; superatletski), ultra- (ultrakolesar, ultrašport, ultrašportnik; ultrakolesarski, ultrašporten). Derivatives with native prefixes are also very productive: nad(nadatlet, nadnogometaš; nadkošarkarski, nadnogometen), naj-(najkošarkar, najnogometaš), ne- (nehokejist, nekegljač, nekolesar, nekošarkar, nekošarkaš, neples, nešport, nešportnik; nehokejski), pra-(prahokej, pranogomet, prasmučar), proti- (protikolesarski, protinogometen), so-(sokolesar). In the category of verbal derivatives with prefixation (Vidovič Muha 1993, 2009), there is an interesting group of verbal derivatives with the following prefixes: $o b$ (obkolesariti), po-(ponogometiti < *nogometiti, pokolesariti, posmučati), pri- (priodbojkirati < *odbojkirati, pribowlati), pre- (presankati) in za-(zasankati se).

\subsection{Potential complex words with a marked morphemic combination}

5.2.0 These complex words make use of predictable word-formational patterns, but they stand out due to their intentionally marked combination of bases and/or affixes. There are several kinds of markedness of combinations.

5.2.1 In the field of sports, markedness in terms of time can be observed in the type of subordinate nominal compounds with interfixation and suffixation (nogometoljubec, plesoljubec, športoljubec), thus reviving the word-formational pattern which is in general becoming less and less productive. In SSKJ, for example, the compound knjigoljubec is labeled as obsolete; the compound plesovodja is similarly obsolete. SSKJ thus contains only 21 compounds of the type knjigovodja, žerjavovodja, etc.

5.2.2 Sociolectal markedness can be reflected in the base or the affix of the word, or in both at the same time. Here we use the definition of sociolect as an established manner of communication within a specific group for the purpose of expressing its own specific perspective and value system (Skubic 2005: 173). Based on the corpus data from this study, we can distinguish at least two major groups of people creating the majority of such marked words, namely journalists, on the one hand, and sports enthusiasts on the other hand. The former use stylistically marked vocabulary in order to attract attention, while the latter use it in order to express their attitude toward a certain variety of sport. In order to determine where connotative lexis comes from and why it was created, the information about the sources in which such words appear can be very helpful. Such information can help to determine whether the studied material represents the word-formational core or the periphery of lexis. It is less probable to find stylistic lexis in technical and scientific literature, because its usage would clash with the main characteristics of expression in this kind of discourse. We therefore assume that in the case of the material from our study, stylistic neologisms belong to marginal lexis, which can be found in non-technical texts. A 
more detailed corpus analysis has confirmed this assumption. The majority of new words from the field of sports come from magazines and newspapers, which FidaPLUS does not label specifically (only the label magazine or newspaper is used). The newspaper Dnevnik, its special editions Nedeljski Dnevnik, Hopla and Pilot, the newspapers Delo, Večer, Vestnik and Štajerski tednik are highly productive sources of new words, while a few examples can also be found in Novi tednik and Dolenjski list. Among magazines, the most productive source of neologisms and nonce words is the magazine Joker. This is not surprising, as Joker is a computer magazine whose Wikipedia entry states that it makes extensive use of archaisms and neologisms. According to Logar Berginc (2004: 196), the use of new complex words in this magazine is an important part of its image. New words also appear in the magazines Mag, Golf Slovenija, MM marketing magazine, Premiera and Mariborčan, and in some online magazines, although to a lesser degree. Taking this into account, the studied words can be characterized as so-called topical new words ("aktualistične nove besede") (Bokal 2000), or journalistic 'topicalisms' ("poročevalski aktualizmi”) (Korošec 1998). It is interesting that the new vocabulary is created in equal measure by newspapers, which are characterized by natural and objective reporting about current topics, and by thematic magazines intended for specific interested audiences, which are usually freer in their expression. New vocabulary from the field of sports is to a large degree created by professional sports journalists (Delo, Dnevnik...), but sports enthusiasts and fans of a particular variety of sport are equally creative (Joker, Golf Slovenia ...).

Marked bases are found in complex words with parallel bases. Such doublet bases appear with nogomet/fuzbal (football/footie), yielding nominal derivations (fuzbalček, fuzbaleršcina, fuzbalšcina) from fuzbal, fuzbaler and fuzbalski. This parallel base also yields an adjectival derivative with prefixation (antifuzbalski), a prefixoid compound (jugofuzbal), and even a group of comopunds with a recognizable suffixoid (a final combining form) -fen (fuzbalfen), -logija (fuzbalogija), -log (fuzbalolog), -manija (fuzbalomanija). There is a similar case with košarka/basket, which yields the formation of the compound minibasket and hybrid derivatives (basketiranje, basketaški, basketas). It is interesting to note that Bajec (1950: 112) observed that in the middle of the $20^{\text {th }}$ century derivation with the suffix - aš was productive particularly in sports terminology (kajakaš, nogometaš, odbojkaš, športaš) under the influence of the neighboring Croatian language. A similar parallel word-formational pattern can be observed in skijanje, skijač, skijaš, skijaški.

Markedness in derivatives with suffixation and compounds with combined interfixation and suffixation can be observed in the case of alternative suffixes,

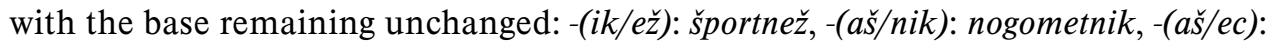
rokometec, -(ist/ec): karatejec, -(ist/ač): golfač, -(ist/(i)at): golfiat, -(lec/ač): plesač. Even a new prefixoid (initial combining form) nogo- is being created (nogometafizika < metafizika nogometa). A special and considerable group consists of nominal derivatives of neuter gender with the suffix $-n j e$. Such derivatives are regularly deverbal in the system of Slovene word-formation, but in this case they are denominal, as it is impossible to extract a verbal base $\left({ }^{*}\right.$ nogometariti $>$ nogometarjenje 'playing foot- 
ball over the internet'). In this case the potential base is the noun *nogometar or nogomet. If we assume that the base is nominal, the suffix -arjenje can be interpreted as the result of perintegration.

A similar type of denominal derivation can be observed in košarkašenje, tenisačenje, With examples such as *košarkirati (košarkiranje, basketiranje, fitnesiranje, tenisiranje), the implied bases are hypothetical verbs of the type -irati. The adjectival formation nogometalen is also stylistically marked, because it replaces the regular suffix -en with the deverbal suffix -alen which is used for denominal adjectival derivatives.

Markedness of the base and the affix can be observed in the example of compounds ( ̌sportoholičen, boksarskonazorski, plesolomen, tenisšpilen) and in the feminine derivative with the suffix -čarka (plesoholičarka), for which the base *plesoholičar or *plesoholik has not been found in the corpus.

It is interesting to note that despite today's flood of the so-called e-formations, only one such example in low frequency lexis from the field of sports could be found (e-smučarščina).

\subsection{Nonce words}

5.3.1 Nonce words are characterized by the use of individual word-formational patterns and considerable creativity, also through the use of word play. Such examples manipulate existing syntactic structures, but use morphological operations which do not exist in natural language (Bat-El 2000: 66) The ad-hoc nature of such formations is shown in the fact that they do not fill any lexical gaps, because there already is a stylistically neutral expression in the lexical system. The established expression, however, cannot carry over the author's conscious expressiveness.

5.3.1 Word play arises from the phonemic similarity of two words, e.g. golfija (Golfje navadna gol(ju)fija), golfivec (Nikoli ni igral golfa, sedaj pa igra kot gol(ju)fivec), golfissimo (Neverjetno! Bravo, bravissimo! To je golfissimo!). At its base there can also be a word phrase which is truncated; the juxtaposed truncated elements preserve the overlapping element, which is similar to an interfix. Here we could use the term blends ("prekrivanke"), which are similar to compounds in that they consist of at least two lexemes but are formed according to a pattern which contains more irregularity than the pattern for creating compounds (Dressler and Merlini Barbesi 1994, quoted in Bat-El 2000: 63). Algeo (1977: 48, quoted in Lehrer 2007: 1116) defines blends as compounds which consist of one word and a part of another word or two (occasionally three) parts of words or truncations which cannot exist as independent units (Lehrer 2007: 116), e.g. nogogazem (< nogo(metni or)gazem), smučarajanje (smučar(sko) rajanje), smučanorija (smuča(rska) norija), smučerator (< smučar(ski koment)ator), with the replacement of $a$ for $e$.

5.3.2 Many nonce words are formed as a consequence of the use of a new motivating word, for example in the case of football and its word family (nogobrc, nogobrcar, nogohitrec, nogoljublje 'love of football', nogovanje 'artistic playing of football') or ball sports 
in general (žogošport, žogošporten). In similar cases there is a replacement of a foreign morpheme by a native morpheme (brcoboks < kikboks, brcoboksar < kikboksar).

The flouting of syntactic rules can be observed in the formation of gerunds, which would normally be formed from imperfective verbs, as in the example prekolesarjenje. The corpus also shows no examples of the verb * razkolesariti for the past participle razkolesarjen.

There are also examples of atypical word-formational analogy, such as slačinogometaš on the analogy with slačipunca, golfizem on the analogy with turizem (e.g. Madeira je in bo $v$ golfu ena izmed mek evropskega zimskega golfizma, čeprav je res, da je cenovno $v$ precej višjem razredu $v$ primerjavi s celinskimi igrišči $v$ Španiji, na Portugalskem, da o cenenih golfskih počitnicah $v$ Tuniziji in Turčiji ne govorimo.). There are also atypical combinations of root constituents in compounds with the zero interfix (golfhec, golfsafari, rolerhokej, karateseks), in addition to those with the more usual interfix -o- (nogoodbojka).

5.3.3 The corpus data also contains the multi-constituent coordinate adjectival compound rokometnonogometnekošarkarskokolesarski (Veseli nas, da ste tudi član rokometnonogometnekošarkarskokolesarske rekreativne ekipe), which is spelled as a juxtaposed compound, but can only be interpreted as (a member of) a handball-football and basketball-cycling (recreational teams), and would normally have to be spelled using a blank space and two hyphens.

\section{CONCLUSION}

The study of new complex words in the field of sports presented in this article focuses on the structural-semantic analysis. In terms of word-formation, these words mostly belong to the category of potential complex words, while there are fewer actual nonce words, i.e. individual complex words which are formed according to original patterns. In the category of potential complex words, prefixoid compounds (kvazišportnik, psevdoatletika) and suffixoid compounds (nogometolog, golfmanija) are predominant. Nonce words are strongly stylistically marked, because in most cases they exist as parallel expressions for denoting phenomena which already have a name. (e.g. brcoboks $=$ kikboks, nogobrcar $=$ nogometaš, tenisarka $=$ tenisačica). This has also been confirmed by the analysis of the sources in which such new words appear. Most of the examples of such new words have been found in daily newspapers and magazines, while only a few examples have been found in other sources, such as fiction (e. g. nogometaška, plesač) or in literature labeled in the corpus as non-fiction literature (e.g. sankaštvo, smučljiv, tenisirati). Authors use word-formational creativity to make their texts more attractive and to have more influence on the readers, who are expected to recognize the stylistic and new meaning of such words. This cannot always be observed solely by focusing on word-formational constituents, so the situational and textual context also has to be taken into consideration. So new complex words, in addition to their expressive function, also have an intellectual function, and both are expressed either by sports enthu- 
siasts who show their love of sports, or by professional journalists who strive for originality in their writing. The professed general purpose of all journalistic news reporting is to inform publicly and objectively about current events, but in today's world of fierce competition even serious news reporting has been influenced by commercialization and even tabloid culture. As a consequence, journalists, similar to advertisers, try to attract attention through linguistic creativity. The following two conclusions can thus be reached: (1) journalistic texts remain the most important source of more recent or unusual words also in the case of sports; (2) the occurrence of neologisms in journalistic texts, which contrary to technical and scientific texts use affective and expressive style to a higher degree, shows that the analyzed examples mainly belong to the peripheral areas of the lexicon, broadening Slovene sports lexis either through not yet established and marked morphemic combinations or through new word-formational patterns.

\section{References:}

BAJEC, Anton (1950) Besedotvorje slovenskega jezika I: Izpeljava samostalnikov. Ljubljana: Ljudska pravica, SAZU.

BAT-EL, Outi (2000) "The grammaticality of 'extragrammatical' morphology." In: U. Doleschal, A. M. Thornton (eds), 61-84.

BOKAL, Ljudmila (1998) "Tipologija novih besed (ob primeru avtomobilskega izrazja)." In: M. Humar (ed), 147-162.

BOKAL, Ljudmila (2000) “Aktualistične nove besede v slovenščini.” In: Z. Jan (ed), 68-76.

FICKO, Simona (2009) Neologismen im Bereich Sport (ein deutsch-slowenischer Vergleich), Diplomarbeit. Maribor: Filozofska fakulteta.

KALIN GOLOB, Monika (2008) "SMS-sporočila treh generacij." In: M. Košuta (ed), 283-294. KOROŠEC, Tomo (1998) Stilistika slovenskega poročevalstva. Ljubljana: Kmečki glas.

KRIŽAJ ORTAR, Martina/BEŠTER TURK, Marja et al. (2000) Na pragu besedila 2. Učbenik za slovenski jezik v 2. letniku gimnazij, strokovnih in tehniških šol. Ljubljana: Rokus.

LEHRER, Adrienne (2007) "Blendalicious.” In: J. Munat (ed), 115-133.

LOGAR BERGINC, Nataša (2004a) "Nove tehnologije in nekateri nesistemski besedotvorni postopki.” In: E. Kržišnik (ed), 121-132.

LOGAR BERGINC, Nataša (20004b) "Nove tvorjenke v publicistiki.” In: M. Kalin Golob, M. Poler Kovačič (eds), 175-199.

MARTINCOVÁ, Olga (1972) "K problematice lexikalnich neologismu." Slovo a slovesnost 33/4, 283-293.

MUHVIĆ-DIMANOVSKI, Vesna (2005) Neologizmi. Problemi teorije i primjene. Zagreb: Zavod za lingvistiku Filozofskoga fakulteta Sveučilišta u Zagrebu.

NIKOLIĆ-HOYT, Anja (2004) Konceptualna leksikografija: prema tezaurusu hrvatskoga jezika. Zagreb: Hrvatska sveučilišna naklada.

Revija Joker.18 June 2011. http://sl.wikipedia.org/wiki/Joker_(revija).

SKUBIC, Andrej E. (2005) Obrazi jezika. Ljubljana: Študentska založba. 
STRAMLJIČ BREZNIK, Irena (2003) "Besedotvorna tipologija novonastalega besedja s področja mobilne telefonije." Slavistična revija. Zbornik referatov za XIII. mednarodni slavistični kongres, 15.-21. avgust 2003, 105-118.

STRAMLJIČ BREZNIK, Irena (2004) Besednodružinski slovar slovenskega jezika. Poskusni zvezek za iztočnice na B. Maribor: Slavistično društvo Maribor.

STRAMLJIČ BREZNIK, Irena (2007) "Historiat poimenovalne in pojmovne raznolikosti za leksemske združbe v slovenistiki". Časopis za zgodovino in narodopisje 78 = n. v. 43/1, 97-109.

STRAMLJIČ BREZNIK, Irena (2010) "Besedotvorne lastnosti slovenskih okazionalizmov." In: E. Vasil' evna Petruhina (ed), 352-363.

STRAMLJIČ BREZNIK, Irena/VORŠIČ, Ines (2009) "Grafoderivati v tiskanih oglasih." Teorija in praksa 46/6, 826-838.

TOPORIŠIČ, Jože (1992) Enciklopedija slovenskega jezika. Ljubljana: CZ.

TOPORIŠIČ, Jože (1996) Slovenski jezik in sporočanje 2. Maribor: Založba Obzorja Maribor.

TOPORIŠIČ, Jože (2000) Slovenska slovnica. Maribor: Založba Obzorja.

TRIER, Jost (1931) Der deutsche Wortschatz im Sinnezirk der Verstandes: Die Geschichte eines sprachlichen Feldes, Band I: Von den Anfängen bis zum Beginn des 13 Jh. Heidelberg.

VIDOVIČ MUHA, Ada (1993) "Glagolske sestavljenke - njihova skladenjska podstava in vezljivostne lastnosti: z normativnim slovensko-nemškim vidikom.” Slavistična revija 41/1, 161-192.

VIDOVIČ MUHA, Ada (2000) Slovensko leksikalno pomenoslovje: govorica slovarja. Ljubljana: Znanstveni inštitut Filozofske fakultete.

VIDOVIČ MUHA, Ada (2009) "Skladenjska interpretacija glagolskih predponskih obrazil vprašanje propozicije." Slavistična revija 57/2, 251-261.

VUKOVIĆ, Petar (2011) “Haller, Jakobson i jezična globalizacija ante litteram.” In: B. KryżanStanojević (ed), 19-38.

\section{Linguistic sources:}

DORNSEIFF, Franz (2004) Der deutsche Wortschatz nach Sachgruppen. Berlin: W. de Gruyter. FidaPLUS. 10 June 2011. http://the.sketchengine.co.uk/.

Seznam športov. 15 June 2011. http://sl.wikipedia.org/wiki/Seznam_\%C5\%A1portov.

Sketch Engine. 10. June 2011. http://the.sketchengine.co.uk/.

SSKJ = Slovar slovenskega knjižnega jezika z Odzadnjim slovarjem slovenskega jezika in Besediščem slovenskega jezika z oblikoslovnimi podatki, Elektronska izdaja na plošči CDROM. Ljubljana 1998.

$S P=$ Slovenski pravopis, 2001. J. TOPORIŠIČ (ed). Ljubljana: SAZU in Znanstvenoraziskovalni center SAZU. 


\section{Abstract \\ WORD-FORMATIONAL PRODUCTIVITY OF THE SLOVENE LANGUAGE IN THE CASE OF SPORTS NEOLOGISMS}

Newly created words are a frequent topic of research in modern linguistics. The reason for this is that innovation processes in lexicon are a reflection of dynamic tendencies which occur as a consequence of modern communication requirements. This contribution focuses on the field of sports, using a corpus approach based on the Sketch Engine (SkE). It investigates formations in Slovene with low frequency (e.g. nogometoljubec, karatejka, sankijada). Based on their morphemic structure, it determines whether they are potential neologisms, which are created according to a productive pattern, or nonce formations, which are created according to individual patterns connected with specific text usage, and which as ad-hoc formations do not belong to the productive word-formational patterns. In light of these findings, the question of the combinations of domestic and foreign word-formational elements will be discussed, and consequently also the question of the hybridization of Slovene formations today. The corpus-based approach will enable us to determine whether the analysed material represents a word-formational core or periphery of the lexicon.

In order to detect new lexical processes, it is necessary to investigate atypical word-formational processes which open up the creative potential of language. They testify to the dynamic nature of language and to its capability to respond to the different needs of different users in different circumstances.

\section{Povzetek \\ BESEDOTVORNA PRODUKTIVNOST SLOVENŠČINE NA PRIMERU NOVOTVORJENK S PODROČJA ŠPORTA}

Raziskovanje novonastajajočih besed predstavlja aktualno področje sodobnega jezikoslovja, saj so inovacijski procesi v leksiki odsev dinamičnih teženj, ki jih narekujejo sodobne komunikacijske potrebe. Prispevek na primeru pomenskega polja šport s korpusnim pristopom v orodju SkE prikazuje tvorjenke z nizko frekvenco (npr. nogometoljubec, karatejka, sankijada) in na podlagi njihove morfemske strukture ugotavlja, ali gre za potencialne novotvorjenke, nastale po produktivnih vzorcih, ali za priložnostnice, tvorjene po individualnih vzorcih, vezanih na specifično besedilno rabo, zato pa poimenovalno fakultativne ter brez sistemotvorne možnosti. S tem bo nakazano vprašanje kombinatorike domačih in prevzetih tvorbenih prvin in vprašanje hibridizacije slovenskih tvorjenk danes. Uporabljeni korpusni pristop bo z analizo virov omogočal diagnosticirati, ali gradivo predstavlja besedotvornovzorčni jedrni ali periferni del leksike.

Če hočemo detektirati nove leksikalne procese, se mora besedotvorje nujno zanimati za jezikovnosistemsko besedotvorno atipiko, ki v jezik prinaša novi tvorbeni nemir in ustvarjalni potencial, s katerim se dokazuje živost jezika ter njegova sposobnost odzivanja na različne potrebe različnih uporabnikov $\mathrm{v}$ različnih okoliščinah. 